\title{
Mathematical Modeling Effect Habbatussauda on Diabetes Mellitus
}

\author{
Sugiyanto*, Luqyana Khalda'Aesa \\ Departement Mathematics, Universitas Islam Negeri Sunan Kalijaga, 55281, Yogyakarta, Indonesia \\ Email*: sugimath@yahoo.co.id
}

\begin{abstract}
Habbatussauda is one of the traditional or herbal medicine existed since a long time ago and this is one of the drugs that was recommended by the Prophet Muhammad. Habbatussauda's benefits has been studied extensively in the field of health, habbatussauda also has been widely used to cure various diseases although it takes a long time. One of the benefit is to cure diabetes mellitus. This research will analyze the mathematics models of diabetes using three variables which are glucose, insulin and insulin generalization. Then it will look for the differences before and after consuming habbatussauda by using the mathematics model.
\end{abstract}

Keywords: Diabetes Mellitus, Habbatussauda, Mathematical Model

\section{INTRODUCTION}

The population of Indonesia is 268.015 .313 in 2018 . Indonesia ranks fourth as the biggest population country, more people living in a country will certainly make many problems arise, one of them is health problem. Some health problems that frequently occur in Indonesia are increased blood sugar, increased blood pressure, obesity, children smoking behavior around 15 years old and older, and many more. While the diseases cause death are stroke, coronary heart disease, diabetes mellitus, respiratory infections, tuberculosis, liver cirrhosis, lung disease, hypertension (high blood pressure.

Diabetes mellitus is a serious chronic disease that occurs because the pancreas does not have insulin (the hormone that regulates blood sugar or glucose), or when the body can't effectively use the produced insulin. According to Consensus Society of Endocrinology Indonesia (PERKENI) 2015 diabetes mellitus diagnosis criteria are the examination of the fasting plasma glucose $\geq 126 \mathrm{mg} / \mathrm{dl}$, the examination of plasma glucose $\geq 200$ $\mathrm{mg} / \mathrm{dl}$ at 2 hours after oral glucose tolerance test (OGTT) with 75 grams of glucose load or plasma glucose tests as $\geq 200 \mathrm{mg} / \mathrm{dl}$ with classic complaint or examination $\mathrm{HbA} 1$ more than equal to 6.5 per 100 by using a standardized method by the National Glycohaemoglobin Standardization Program (NGSP).

It makes a lot of Indonesian looking for medicine to heal or just make it as a preventer of various disease. One of it with herbal treatments which currently in great demand, one of them is nigella sativa, or commonly known as black seed or habbatussauda.

Habatussauda is one of the traditional medicine that has begun to be used by physicians to treat various diseases, Prophet Muhammad said that Black Seed can cure all diseases except death. Medicine that uses natural contemporary ways in worldwide have been using the habbatussauda contains Thymoquinone as a major component. Thymoquinone is a compound found in habbatussauda. Thymoquinone has a function of protection against toxic effects of chemicals toxic to the kidneys (nephrotoxicity) and liver damage caused by chemicals (hepatotoxicity). It also has an antiinamasi activity (relieving inflammation), analgesics (pain relievers), antipyretics (fever), antimicrobial (exterminator microbes).

The development of knowledge about the benefits of habbatussauda in medical science is quite a lot and is still being developed. Habbatussauda's benefits can be analyzed with mathematics, using mathematical modeling. In this model will discuss the modeling of diabetes mellitus which influenced by habbatussauda.

\section{METHOD}

\section{Establishment of Model of Diabetes Mellitus}

In this study diabetes mellitus model refers to Sandhya and Deepak Kumar journal in 2011, [2], model formulated by using three factors, namely $G(t), X(t)$ and $I(t)$, With $G(t)$ is the plasma glucose concentration at time $t(\mathrm{mg} / \mathrm{dl}), X(t)$ is equated insulin generalization variable in every part $\left(\mathrm{min}^{-1}\right)$, and $I(t)$ is the plasma insulin concentration at time $t(\mu \mathrm{U} / \mathrm{ml})$. The assumptions used in this model is a suffered disease only diabetes mellitus using only three variables, the amount of plasma glucose, plasma insulin and the amount of insulin generalization of each section.

The amount of three factors above stated $N(t)=G(t)+X(t)+I(t)$. The variables and parameters used in this model are as follows in Table 1. 
Table 1. List of Variables and Parameters.

\begin{tabular}{|c|c|c|c|}
\hline No. & Symbol & Information & Unit \\
\hline 1. & $G(t)$ & $\begin{array}{l}\text { The plasma glucose } \\
\text { concentration at time } t\end{array}$ & $\mathrm{mg} / \mathrm{dl}$ \\
\hline 2. & $X(t)$ & $\begin{array}{l}\text { The generalized insulin variable } \\
\text { for the remote compartment }\end{array}$ & $\min ^{-1}$ \\
\hline 3. & $I(t)$ & $\begin{array}{l}\text { The plasma insulin concentration } \\
\text { at time } t\end{array}$ & $\mu \mathrm{U} / \mathrm{ml}$ \\
\hline 4. & $g_{b}$ & $\begin{array}{l}\text { This is the basal preinjection } \\
\text { value of plasma glucose }\end{array}$ & $\mathrm{mg} / \mathrm{dl}$ \\
\hline 5. & $i_{b}$ & $\begin{array}{l}\text { This is the basal preinjection } \\
\text { value of plasma insulin }\end{array}$ & $\mu \mathrm{U} / \mathrm{ml}$ \\
\hline 6. & $m_{1}$ & $\begin{array}{l}\text { Insulin independent rate constant } \\
\text { of glucose rate uptake in } \\
\text { muscles, liver and adipose tissue }\end{array}$ & $\min ^{-1}$ \\
\hline 7. & $m_{2}$ & $\begin{array}{l}\text { Insulin independent rate constant } \\
\text { of glucose rate uptake in } \\
\text { muscles, liver and adipose tissue }\end{array}$ & $\min ^{-1}$ \\
\hline 8. & $m_{3}$ & $\begin{array}{l}\text { The insulin independent increase } \\
\text { in glucose uptake ability in } \\
\text { tissue per unit of insulin } \\
\text { concentration } i_{b} \text {. }\end{array}$ & $\min ^{-2} \cdot(\mu \mathrm{U} / \mathrm{dl})$ \\
\hline 9. & $m_{4}$ & $\begin{array}{l}\text { The rate of the pancreatic } \beta \text { - } \\
\text { cells' release of insulin after the } \\
\text { glucose injection and with } \\
\text { glucose concentration above h }\end{array}$ & $\begin{array}{l}(\mu \mathrm{U} / \mathrm{dl}) \cdot \min ^{-2} \\
.(\mathrm{mg} / \mathrm{dl})^{-1}\end{array}$ \\
\hline 11. & $m_{5}$ & $\begin{array}{l}\text { The threshold value of glucose } \\
\text { above which the pancreatic } \beta \text { - } \\
\text { cells release insulin. }\end{array}$ & \\
\hline 12. & $m_{6}$ & $\begin{array}{l}\text { The first order decay rate for } \\
\text { insulin in plasma }\left(\mathrm{h}^{-1}\right) \\
\text { pancreatic } \beta \text {-cells release insulin. }\end{array}$ & $\min ^{-1}$ \\
\hline
\end{tabular}

In this model the number of plasma glucose in the body over time $t$ is affected by the declining value of fixed-free insulin to glucose and then multiplied by the number of existing plasma glucose. Total plasma glucose over time $t$ is also affected by increasing levels of glucose reduction, multiplied by the number of existing insulin plasma. In addition the number of plasma glucose at time $t$ is also influenced by the increase of fixed-free insulin value to glucose is multiplied with the glucose initial value before the injection.

Generalization of insulin from any part influenced by the reduction in the rate of reduction of glucose multiplied with generalization of insulin from each section, also influenced by the increased concentration of insulin $i_{b}$ on every tissue increases insulin free in fasting glucose multiplied by the number of insulin itself, is also affected by a reduction in insulin concentration $i_{b}$ on every tissue increasing insulin free in fasting glucose but is multiplied with the initial value of insulin before the injected, but it also influenced by the increased in the first decay rate of plasma insulin in pancreas plasma $\beta$ cells multiplied with the initial value before insulin injection.

Furthermore, the number of plasma insulin in the body at time $t$ is affected by a reduction of insulin concentration $i_{b}$. In every tissue increasing free insulin on glucose fasting plasma multiplied by the number of insulin in the body. Plasma insulin was also influenced by the increase in the release rate of insulin in pancreatic $\beta$-cells after injection of glucose with glucose concentration over $\mathrm{h}$ multiplied by the number of plasma glucose in the body. It is also influenced by the increase in the rate of $\beta$ insulin release in the pancreas after injection of glucose with glucose concentration over $h$ but multiplied by the amount of glucose when cells $\beta$ in the pancreas releases insulin, the reduced rate of decay of the first insulin on plasma pancreatic $\beta$-cells multiplied by the number of plasma insulin that exist in the body, and also by the first decay rate reduced plasma insulin in first decay pancreas plasma $\beta$-cells but multiplied by the number of insulin before injection. Therefore is obtained Equation (1), (2), and (3).

$$
\begin{aligned}
& \frac{d G}{d t}=-m_{1} G+m_{2} I+m_{1} g_{b} \\
& \frac{d X}{d t}=-m_{2} X+m_{3} I-m_{3} i_{b}+m_{6} i_{b} \\
& \frac{d I}{d t}=-m_{3} I+m_{4} G+m_{4} m_{5}-m_{6} I+m_{6} i_{b}
\end{aligned}
$$

\section{The Stability of The Equilibrium Point}

Obtained equilibrium point value, $E_{q 0}$, of the equations above with notations on this modeling is $G_{0}, X_{0}$, and $I_{0}$. Theorem 1 is given as follows.

Theorem 1. The System (1), (2) and (3) has the equilibrium point, $E_{q 0}$,

$$
\begin{aligned}
& G_{0}=\frac{m_{2} m_{4} g_{b}+m_{2} m_{4} m_{5}+m_{2} m_{6} i_{b}}{m_{1} m_{3}-m_{2} m_{4}+m_{1} m_{6}}+g_{b} \\
& X_{0}=\frac{m_{1} m_{3}\left(m_{4} g_{b}+m_{4} m_{5}+m_{6} i_{b}\right)+\left(m_{6} i_{b}-m_{3} i_{b}\right)\left(m_{1}\left(m_{3}+m_{6}\right)-m_{2} m_{4}\right)}{m_{2}\left(m_{1}\left(m_{3}+m_{6}\right)-m_{2} m_{4}\right)} \\
& I_{0}=\frac{m_{1} m_{4} g_{b}+m_{1} m_{4} m_{5}+m_{1} m_{6} i_{b}}{m_{1} m_{3}-m_{2} m_{4}+m_{1} m_{6}}
\end{aligned}
$$

Proof. If Equation (1) is substituted to Equation (3), then it is obtained $G_{0}=\frac{m_{2} m_{4} g_{b}+m_{2} m_{4} m_{5}+m_{2} m_{6} i_{b}}{m_{1} m_{3}-m_{2} m_{4}+m_{1} m_{6}}+g_{b}$ and $\quad I_{0}=\frac{m_{1} m_{4} g_{b}+m_{1} m_{4} m_{5}+m_{1} m_{6} i_{b}}{m_{1} m_{3}-m_{2} m_{4}+m_{1} m_{6}}$. If $\quad I_{0} \quad$ is substituted to Equation (2), then it is obtained

$$
X_{0}=\frac{m_{1} m_{3}\left(m_{4} g_{b}+m_{4} m_{5}+m_{6} i_{b}\right)+\left(m_{6} i_{b}-m_{3} i_{b}\right)\left(m_{1}\left(m_{3}+m_{6}\right)-m_{2} m_{4}\right)}{m_{2}\left(m_{1}\left(m_{3}+m_{6}\right)-m_{2} m_{4}\right)} .
$$

Theorem 2. The equilibrium point exist if $G_{0}, X_{0}, I_{0}$ is real and non-negative.

Proof. Existence of the equilibrium point above exist if $G_{0}, X_{0}, I_{0}$ is real and non-negative. 
1. $G_{0}$ is real and non-negative, which $m_{1} m_{3}+m_{1} m_{6}-m_{2} m_{4}>0$.

2. $X_{0}$ is real and non-negative $m_{1} m_{3}+m_{1} m_{6}-m_{2} m_{4}>0$ and $m_{1} m_{3}\left(m_{4} g_{b}+m_{4} m_{5}+m_{6} i_{b}\right)+\left(m_{6} i_{b}-m_{3} i_{b}\right)\left(m_{1}\left(m_{3}+m_{6}\right)-m_{2} m_{4}\right) \geq 0$.

3. $I_{0}$ is real and non-negative, which $m_{1} m_{3}+m_{1} m_{6}-m_{2} m_{4}>0$

The obtained equilibrium point will be discussed about the stability in the point diabetes mellitus model above.

Theorem 3. The equilibrium point, $E_{q 0}$, System (1) (3) will be asymptotically stable locally if $\left(m_{1}+m_{3}+m_{6}\right)^{2}=4\left[m_{1}\left(m_{3}+m_{6}\right)-m_{2} m_{4}\right]$.

Proof. The eigenvalues of the Jacobian matrix are as follows.

$$
\begin{aligned}
\lambda_{1} & =-m_{2}<0, \\
\lambda_{2}= & \frac{-\left(m_{1}+m_{3}+m_{6}\right)+\sqrt{\left(m_{1}+m_{3}+m_{6}\right)^{2}-4\left[m_{1}\left(m_{3}+m_{6}\right)-m_{2} m_{4}\right]}}{2} \\
\lambda_{3}= & \frac{-\left(m_{1}+m_{3}+m_{6}\right)-\sqrt{\left(m_{1}+m_{3}+m_{6}\right)^{2}-4\left[m_{1}\left(m_{3}+m_{6}\right)-m_{2} m_{4}\right]}}{2} \\
& \text { If } \quad\left(m_{1}+m_{3}+m_{6}\right)^{2}=4\left[m_{1}\left(m_{3}+m_{6}\right)-m_{2} m_{4}\right],
\end{aligned}
$$
then $\lambda_{1}<0, \quad \lambda_{2}<0, \quad \lambda_{3}<0$. This means that the equilibrium point is asymptotically stable locally.

\section{RESULT AND DISCUSSION}

\section{Simulations}

Numerical simulation in this study use Matlab R2016a to provide a value for each parameter used in the model. Numerical simulations are given to illustrate geometrically from diabetes disease model using data of glucose values before and after consuming habbatussauda with primary data collection. The data obtained directly, conducted on 20 respondents were given habbatussauda for 14 days which consume 3 capsules per day. The average value of glucose in the blood before taking habbatussauda is $90.3 \mathrm{mg} / \mathrm{dl}$ and the average value of $86.4 \mathrm{mg}$ after consuming habbatussauda. The value of each parameter is as follows in Table 2.

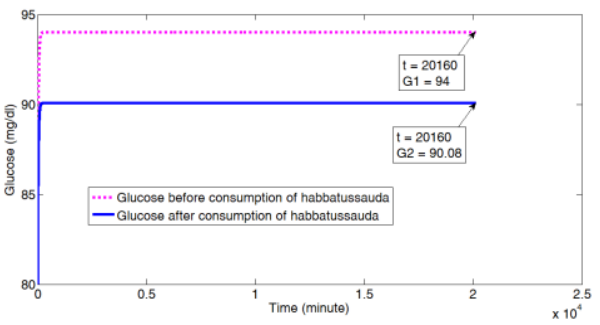

Figure 1. Trajectory glucose before and after consumption of habatussauda within 14 days.

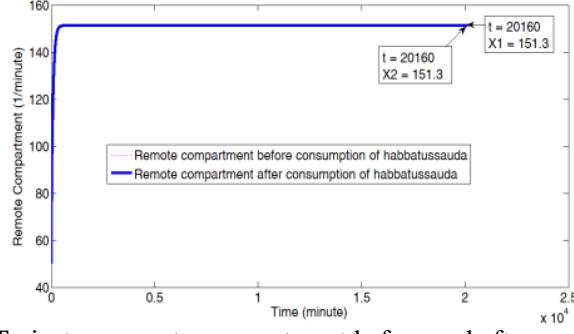

Figure 2. Trajectory remote compartment before and after consumption of habatussauda within 14 days.

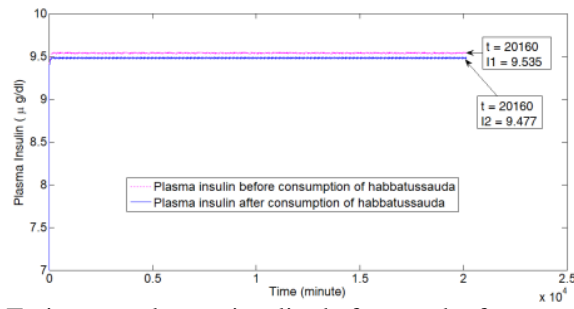

Figure 3. Trajectory plasma insulin before and after consumption of habatussauda within 14 days

Table 2. Parameter value of disease diabetes mellitus.

\begin{tabular}{llll}
\hline No. & Parameter & Value & Unit \\
\hline 1. & $g_{b}$ before consumption & 90.3 & $\mathrm{mg} / \mathrm{dl}$ \\
habbatussauda & & \\
2. & $g_{b}$ after consumption & 86.4 & $\mathrm{mg} / \mathrm{dl}$ \\
& habbatussauda & & \\
3. & $i_{b}$ & 7 & $\mu \mathrm{U} / \mathrm{ml}$ \\
4. & $m_{1}$ & 0.0317 & $\mathrm{~min}^{-1}$ \\
5. & $m_{2}$ & 0.0123 & $\mathrm{~min}^{-1}$ \\
6. & $m_{3}$ & $4.92 \times 10^{-6}$ & $\mathrm{~min}^{-2} \cdot(\mu \mathrm{U} / \mathrm{dl})$ \\
7. & $m_{4}$ & 0.0039 & $(\mu \mathrm{U} / \mathrm{dl}) . \mathrm{min}^{-2}$ \\
8. & $m_{5}$ & 79.0353 &.$\left(\mathrm{mg}^{2} \mathrm{dl}\right)^{-1}$ \\
9. & $m_{6}$ & 0.2659 & $\mathrm{~min}^{-1}$ \\
\hline & & & \\
\hline
\end{tabular}

The equilibrium point obtained from this model will be shown by numerical simulations in the portrait phase at the equilibrium point using the corresponding parameter values as shown in Table 2. The variables used in this simulation are variables namely glucose and insulin variables, the value before consuming habbatussauda is 90.3 and the value before consuming habbatussauda is 86.4. The initial value in this simulation is $(G, X, I)=(80,50,7)$.

Figure 1 shows before and after consuming habbatussauda decreased glucose levels in the body. But the obtained reduction is different, it shows the effect of habbatussauda consumption decreases glucose levels significantly enough compared to the decreasing rate of glucose levels before taking habbatussauda. Decreased glucose levels before taking habbatussauda only reached 90.3 only, while a decrease in glucose levels after consuming habbatussauda reach 86.4. The rate of this 
change would be more significant if habbatussauda consumption in a longer period of time.

Figure 2 shows the remote compartment variable, $\mathrm{X}$, values before and after consumption of Black Seed. To consume habbatussauda or not the remote compartment has not changed. The value of survivors 20160 minutes or 14 days is $151.3 \mathrm{~min}^{-1}$.

Figure 3 shows plasma insulin before and after consuming habbatussauda. After consuming Black Seed there is a decrease though small. Before consuming habbatussauda is $9,535 \mu \mathrm{g} / \mathrm{dl}$ and after consuming habbatussauda is $9,477 \mu \mathrm{g} / \mathrm{dl}$.

\section{CONCLUSION}

Numerical simulation results in the first model showed differences in glucose levels before and after consuming habbatussauda. The results of the second simulation show the same position the content of the remote compartment before and after consuming habbatussauda. Simulation results show the position of a small difference in plasma insulin content before and after consuming habbatussauda.

\section{REFERENCES}

Abdulelah, HAA and Abidin, ZBAH 2007. In vivo Anti-malarial Tests of Nigella sativa (black seed) Different Extracts. American Journal of Pharmacology and Toxicology 2 (2): 4650 .
Ahmad, Aftab, et al. 2013. A Review on the Therapeutic Potential of Nigella sativa: A Miracle Herb. Asian Paci fi c Journal of Tropical Biomedicine.

Decroli, E., Kam, A., \& Dillasamola, D. 2019. The percentage of depressive symptoms in patients with type 2 Diabetes Mellitus in M Djamil General Hospital Padang, Indonesia. Marmara Pharmaceutical Journal, 23(2).

Monica, W., Widyaningsih, V., \& Sulaeman, E. S. 2019. Metaanalysis on The Effects of Hypertension, Type II Diabetes Mellitus, and Smoking on the Risk of Stroke among Asian Young Adult Population. Journal of Epidemiology and Public Health, 4(4), 296-306.

Osman, Mohamed T, Hamja, et al. 2012. The New Miracle of Habbatus Sauda: Its Major Component Thymoquinone Can Be Used in the Management of Autoimmune Diseases. Universiti Teknologi MARA. Selangor. Malaysia.

Rosado, Yesenia Cruz. 2009. Mathematical Model for Detecting Diabetes. Department of Mathematics The University of Puerto Rico at Humacao. Humacao.

Shandya and Kumar, Deepak. 2011. Mathematical Model for Glucose-Insulin Regulatory System of Diabetes Mellitus. Advances in applied mathematical biosciences, 2 (1), 39-46.

World Health Organization (WHO) Consultation. 2015. Indonesia: WHO statistical profile. 